\title{
Diaphragmatic rupture: A single-institution experience and literature review
}

\author{
Carlo Corbellini, M.D., Stefano Costa, M.D., Tiberio Canini, M.D., \\ Roberta Villa, M.D., Ettore Contessini Avesani, M.D.
}

Department of General Surgery and Emergency Surgery, Fondazione IRCCS Cà Granda, Ospedale Maggiore Policlinico, Milan-Italy

\begin{abstract}
BACKGROUND: Diaphragmatic rupture (DR) is a rare and potentially life-threatening event caused by trauma or spontaneously. DR occasionally occurs several months after the injury. Chest X-ray and computed tomography are the most effective diagnostic methods. Delay in DR diagnosis occurs frequently. This study aimed to examine and improve our understanding of the etiology, clinical presentation, and management of DR.

METHODS: This study was performed at the Emergency and General Surgery Department of Fondazione I.R.R.C.S. Cà Granda, Ospedale Policlinico in Milan (Italy). Patients diagnosed with DR between $200 \mathrm{I}$ and $20 \mathrm{II}$ who underwent surgery were included, and their data were retrospectively collected.

RESULTS: Fourteen patients were diagnosed with DR, mainly left-sided DR. Road traffic collisions were the main causes (86\%). DR diagnosis was preoperatively established in eight patients (57\%). Chest X-ray was diagnostic in $50 \%$ of the patients and computed tomography in three patients $(60 \%)$. Twelve patients had a diaphragmatic hernia. DR was repaired with a mesh in two patients. Mean hospital stay was 16.6 days.
\end{abstract}

CONCLUSION: Difficulty in achieving early diagnosis of DR is due to its nonspecific presentation. High index of suspicion is needed. Its treatment is using surgery involving reduction of the viscera and repair of the diaphragm defect.

Keywords: Diaphragmatic hernia; diaphragmatic rupture; spontaneous diaphragmatic rupture; traumatic diaphragmatic rupture.

\section{INTRODUCTION}

Diaphragmatic rupture (DR) is a rare pathological event that is commonly caused by trauma, as that in road traffic accidents (RTAs) or penetrating injuries. ${ }^{[1-3]} \mathrm{DR}$ diagnosis can be immediate or delayed after the main trauma. A different cause of DR is represented by spontaneous DR (SDR). Diaphragmatic hernia $(\mathrm{DH})$ occurs when one or more abdominal structures protrude through the diaphragm.

Address for correspondence: Carlo Corbellini, M.D.

Department of General Surgery and Emergency Surgery,

Fondazione IRCCS Cà Granda, Ospedale Maggiore Policlinico -

20122, Via Francesco Sforza, 36 - Milan, Italy

Tel: +39-02-55033298 E-mail: carlo.corbellini@yahoo.it

Submitted: 01.03.2016

Accepted: 24.01.2017

Ulus Travma Acil Cerrahi Derg

20I 7;23(5):42। -426

doi: $10.5505 /$ tjtes.2017.78027

Copyright 2017

TJTES
Symptoms can vary depending on the DR phase and the clinical setting, and thus, the diagnosis can be easily missed. Surgical treatment is usually required to reduce herniated organs and repair the defect.

\section{MATERIALS AND METHODS}

In this study, we evaluated all patients with DR (ICD-9 Codes: 862.XX, 552.3 and 553.3) who were admitted to the Emergency and General Surgery Department (ESD) of Fondazione I.R.C.C.S. Cà Granda, Ospedale Maggiore Policlinico, in Milan (Italy) between January 200 I and December 20I I. Each patient who was diagnosed with DR with or without a history of high-energy trauma and had undergone a surgery was included. Patients with a history of hiatal hernia or congenital $\mathrm{DH}$ were excluded. We could not determine whether the patients admitted at our ESD were misdiagnosed with DR. DR diagnosis was attested using imaging studies or during the surgical procedure. Data were extracted retrospectively and double-checked by two authors (C.C. and R.V.). Patient data regarding age, sex, mechanism of injury, associated injuries, symptoms, diagnostic imaging methods, time to diagnosis 
(time from hospital admission to correct diagnosis), size of rupture, presence of hernia, surgical treatment, postoperative complications and mortality, were evaluated.

\section{RESULTS}

Fourteen patients (nine males and five females) with a mean age of 37 (range, 19-79) years were included. Detailed data on patient characteristics, injury details, diagnosis timing, and clinical outcomes are reported in Table I. RTA was the most common category of trauma (II intervehicular and one pedestrian), whereas one patient had penetrating trauma. A case of spontaneous DR during a gymnastic exercise was reported in our case series. Hemorrhagic shock occurred in six of 10 patients with acute traumatic injury at admission (60\%). The main symptom was dyspnea, and others common symptoms were nausea, chest pain, cough, and epigastric pain. Multiple associated injuries were detected in 10 patients (Table 2), and rib fracture was the most common injury $(70 \%)$.

The diaphragm defect was left-sided in 12 patients (86\%) and right-sided in two (14\%); no bilateral DR was found. Herniation of the abdominal organs into thorax was detected in 12 patients (intraoperatively in nine and preoperatively in three). Detailed data on the herniated organs are presented in Table 3.

DR was preoperatively diagnosed in eight of I 4 patients (57\%) and during surgery in six (43\%). The interval between traumatic event and DR diagnosis ranged from I $\mathrm{h}$ to 96 months. Intraoperative diagnosis was achieved in five of 10 patients
Table 2. Associated injuries

\begin{tabular}{llc}
\hline Body region & Injury description & $\begin{array}{c}\text { No. of } \\
\text { patients }\end{array}$ \\
\hline Head & Closed head injury & 3 \\
& Facial injury & 4 \\
Chest & Pulmonary contusion & 3 \\
& Rib fracture & 7 \\
& Sternum fracture & 1 \\
& Pneumothorax & 2 \\
& Hemothorax & 4 \\
& Vertebral process fracture & 2 \\
& Liver & 1 \\
& Bowel & 1 \\
& Renal & 1 \\
& Spleen with hemoperitoneum & 3 \\
& Spleen without hemoperitoneum & 1 \\
& Upper extremities & 1 \\
\hline \multirow{5}{*}{ Orthopedics } & Lower extremities & 1 \\
& Vertebral & 2 \\
& Spinal cord & 1 \\
& Pelvis & 4 \\
& & 1 \\
& &
\end{tabular}

with acute blunt DR (BDR) (50\%). In four of five patients with acute BDR, the preoperative diagnosis was established in less than $12 \mathrm{~h}$ after arrival at our ESD. Three patients without an

Table I. Characteristics of patients, injury details, timing diagnosis, and clinical outcomes

\begin{tabular}{|c|c|c|c|c|c|c|c|}
\hline No & Gender & $\begin{array}{l}\text { Age } \\
\text { (years) }\end{array}$ & Cause of injury & $\begin{array}{l}\text { Haemorrhagic } \\
\text { shock (Yes/No) }\end{array}$ & $\begin{array}{c}\text { Associated } \\
\text { injuries (Yes/No) }\end{array}$ & $\begin{array}{l}\text { Time to } \\
\text { diagnosis* }\end{array}$ & $\begin{array}{l}\text { Postoperative } \\
\text { complication }\end{array}$ \\
\hline I & Male & 31 & Road traffic accident & Yes & Yes & i.o. & No \\
\hline 2 & Male & 31 & Stab wound (II months before) & No & No & $<12 \mathrm{~h}$ & No \\
\hline 3 & Female & 53 & Road traffic accident & No & Yes & $>12 \mathrm{~h}$ & Yes \\
\hline 4 & Female & 79 & Road traffic accident (pedastrian) & Yes & Yes & $<12 \mathrm{~h}$ & No \\
\hline 5 & Male & 33 & $\begin{array}{l}\text { Road traffic accident } \\
\text { (46 months before) }\end{array}$ & No & No & $<12 h$ & No \\
\hline 6 & Male & 24 & Road traffic accident & No & Yes & i.o. & Yes \\
\hline 7 & Male & 19 & Road traffic accident & Yes & Yes & i.o. & i.o. death \\
\hline 8 & Male & 43 & Road traffic accident & No & Yes & $<12 \mathrm{~h}$ & No \\
\hline 9 & Male & 28 & $\begin{array}{l}\text { Road traffic accident } \\
\text { (96 months before) }\end{array}$ & No & No & $<12 \mathrm{~h}$ & No \\
\hline 10 & Female & 21 & Road traffic accident & Yes & Yes & i.o. & No \\
\hline 11 & Female & 27 & Road traffic accident & Yes & Yes & $<12 \mathrm{~h}$ & No \\
\hline 12 & Male & 43 & Road traffic accident & No & Yes & $<12 \mathrm{~h}$ & No \\
\hline 13 & Female & 41 & Gymnastiic exercise & No & No & i.o. & No \\
\hline 14 & Male & 50 & Road traffic accident & Yes & Yes & i.o. & Yes \\
\hline
\end{tabular}

i.o.: Intra operative diagnosis; "After arrival at the ESD. 
Table 3. Diaphragmatic injury and herniated organs

\begin{tabular}{llc}
\hline Variable & & No. of patients \\
\hline \multirow{2}{*}{ Location } & Right & 2 \\
& Left & 12 \\
& $<6 \mathrm{~cm}$ & 3 \\
& Between 6 and $10 \mathrm{~cm}$ & 8 \\
Herniated organs & $>10 \mathrm{~cm}$ & 3 \\
& Stomach & 7 \\
& Bowel & 5 \\
& Liver & 2 \\
& Spleen & 2 \\
& Omentum & 2 \\
& None & 2 \\
\hline
\end{tabular}

acute injury presented a medical history of previous trauma: one with stab wound II months previously, one with RTA 46 months previously, and another with RTA 96 months previously. These patients presented delayed DR, and dyspnea was the common symptom. Diagnosis was established in these patients in less than $12 \mathrm{~h}$ after arrival at the ESD. The only patient with SDR was preoperatively diagnosed.

The diagnostic methods included chest X-ray, computed tomography (CT), ultrasonography (USG), and oral contrast studies. We obtained chest radiographs from 10 patients, and radiographs of five of them (50\%) were reported as normal. The chest radiographs usually showed nonspecific signs as diaphragm elevation with loss of right costo-diaphragm angle (Figure $\mathrm{Ia}$ and $\mathrm{Ib}$ ). Five hemodynamically stable patients underwent thoracoabdominal CT, in three of whom (60\%), CT scan was diagnostic. In these three patients, chest radiograph findings were consistent with diagnosis on CT scan. Abdominal USG was performed in five patients, which provided specific information concerning DR in two patients (40\%). Two patients underwent a positive $\mathrm{X}$-ray oral contrast study (Figure 2).

All 14 patients underwent surgery. Laparotomy (eight emergency laparotomies) was performed in nine patients and thoracotomy in four. One patient underwent left thoracoabdominal approach. The median size of acute BDR (large diameter) and DR was $8 \pm 2.7 \mathrm{~cm}$ and $5 \pm 4 \mathrm{~cm}$, respectively. The size of rupture in the patient with SDR was $6 \mathrm{~cm}$. The herniated organs were always reduced into the abdomen. The diaphragm defect was repaired with non-absorbable direct suture in 12 patients. In two patients, a polypropylene prosthetic mesh was placed following the primary repair of DR. Splenectomy was performed in five patients: in four of whom, the spleen was herniated in the thorax, and in one, bleeding from an iatrogenic spleen occurred in the absence of herniation. A transverse colon resection with colostomy was performed because of bowel perforation.
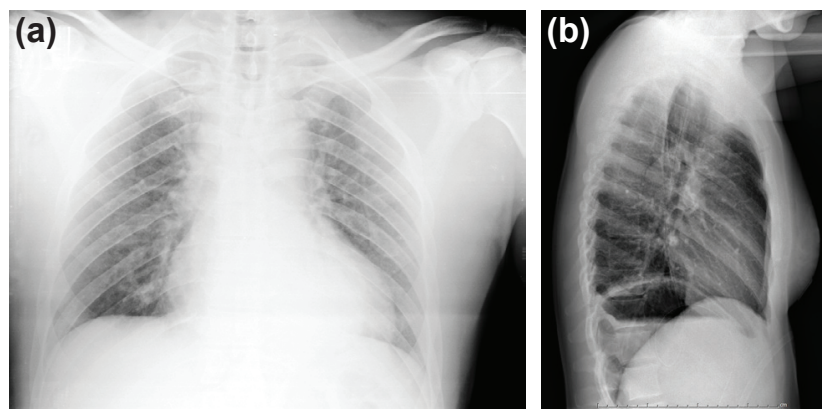

Figure 1. (a) A negative chest radiograph of a patient presenting with BDR (Case 12). (b) A diagnostic posteroanterior chest radiograph of a patient with a delayed DR that had occurred during gymnastic exercise. Immediate decompression with a nasogastric tube was required. An elevated left hemidiaphragm can be observed (Case 13)

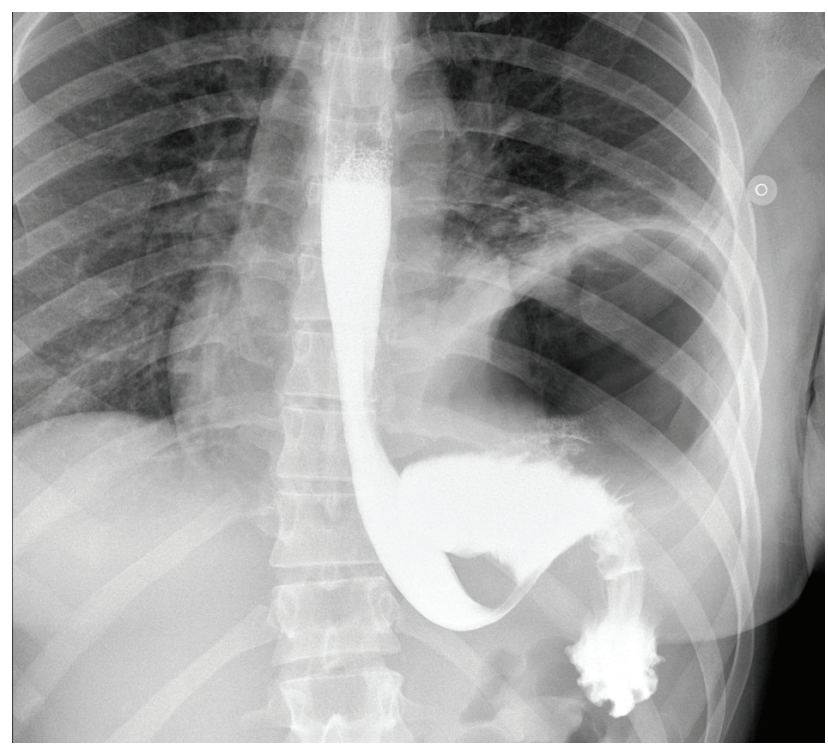

Figure 2. A gastrografin follow-through revealed an elevation and a discontinuity of left hemidiaphragm with herniated stomach into the left hemithorax (Case 13).

A polytraumatized patient died at the end of surgery for cardiocirculatory arrest following hemorrhagic shock. The mean hospital stay was 16.6 (range, 5-53) days. Three patients (27\%) had postoperative pulmonary-related complications, which were successfully treated conservatively. In the other eight patients, recovery was uneventful.

\section{DISCUSSION}

Any event that can lead to a sudden increase in intra-abdominal pressure may result in DR. ${ }^{[4]}$ In 1974, Grimes described three phases for DR. The acute phase denotes the onset of clinical symptoms at the time of injury. Development to the second phase may take months or even years. The delayed phase is explained by two hypotheses: delayed rupture or delayed detection. Missed diagnosis during the early period of trauma may lead to progressive herniation of intra-abdominal contents into the thorax, and occasionally, visceral obstruction or strangulation occurs. ${ }^{[5-7]}$ 
The incidence of diaphragmatic injuries in patients with blunt abdominal trauma is estimated to be $0.8 \%-5 \% .{ }^{[8]}$ RTAs are the most common cause of BDR. ${ }^{[5]}$ In our study, I 2 patients (86\%) had a recent ( 10 patients) or previous (two patients) RTA. BDRs are usually observed in the left diaphragm (68.6\%-87\%) [9] because this area has a weak pleuroperitoneal membrane structure; in contrast, right-side DRs are encountered only in $5 \%-19 \%$ of all DR cases. $^{[10,11]}$ Bilateral hemiDR is rare.

$\mathrm{DH}$ is an unusual condition; it occurs in 1\%-7\% of patients with DR following major blunt trauma and in 10\%-15\% of patients with penetrating trauma and DR. ${ }^{[3]}$ Our case series describes 12 DHs: three DHs with delayed presentation, one $\mathrm{DH}$ due to SDR, and eight DHs detected after acute traumatic injury. The organs most commonly involved in leftsided $\mathrm{DH}$ are the stomach and colon (Table 3). In our study, $\mathrm{DH}$ was a common event because the study mainly involved polytraumatized patients. The displacement of abdominal organs was more common in delayed hernias, which is consistent with the results in literature. Bowel obstruction, without any evidence of ischemia, was observed in two patients, both with delayed presentation of $\mathrm{DH}$.

SDR is an extremely rare condition accounting for less than $1 \%$ of cases of DR. ${ }^{\left[{ }^{9]}\right.}$ SDR is defined as a damage of the diaphragm due to an increased pressure in the chest or abdominal cavity without direct trauma. In our case series, a single case of SDR was observed and it was associated with $\mathrm{DH}$.

Symptoms in patients with DR may vary depending on the DR phase. ${ }^{[12]}$ In blunt or penetrating trauma, DR is usually associated with reduced breath sounds, orthopnea, and dyspnea. ${ }^{[10,13-15]}$ In the study by Popovic et al., ${ }^{[16]}$ the main presenting symptoms were epigastric pain, nausea, vomiting, and meteorism. ${ }^{\left[{ }^{\prime \prime}\right]}$ These evidences demonstrated that the diagnosis can be easily missed. In the literature, a great variability in diagnosis timing has been reported. ${ }^{[8, I I]}$ The rate of initially missed diaphragmatic injuries range from 12\% to $66 \%$ after an acute trauma. ${ }^{[1,18]}$ Many investigation techniques have been described for DR diagnosis, but no diagnostic method has a higher sensitivity or specificity than other methods; nonetheless, CT can be considered as the gold standard in an emergency setting in stable patients. ${ }^{[13,19]}$ In our study, the two most commonly used techniques were chest $X$-ray and CT. In the literature, consistent with our results, it has been reported that only $25 \%-50 \%$ of the initial chest radiographs are diagnostic for BDR. ${ }^{[18,20]}$ Furthermore, sensitivity of CT in diagnosing acute DR ranges between $33 \%$ and $83 \%$, and its specificity ranges between $76 \%$ and $100 \%{ }^{[18,21]} \mathrm{CT}$ findings in acute DR are hemidiaphragmatic discontinuity, intrathoracic herniation of the abdominal content, and the dependent viscera sign. ${ }^{[22,23]}$ In our series, CT revealed a DR in three of five stable polytraumatized patients. A chest X-ray was performed in these three patients, and the findings were consistent with diagnosis on CT. USG may allow the visualization of large DR or DH, but this imaging method is rarely used for first-time investigation. Magnetic resonance imaging can be a good diagnostic tool, but it cannot be performed in an emergency setting. ${ }^{[21]}$ Oral follow-through study was performed in two patients, and it revealed positive results; chest $X$-ray results in both these patients were negative. The patients with SDR demonstrated negative results on chest $X$-ray, chest $C T$, upper gastrointestinal endoscopy, and abdominal USG before being diagnosed using oral follow-through. In our patients with delayed $\mathrm{DR}$, the diagnostic approaches were varied: two patients underwent X-ray barium enema because of bowel obstruction presentation, and in one patient, CT scan was diagnostic for right-sided $\mathrm{DH}$ associated with liver and colon herniation. As frequently observed, the preoperative diagnostic rate of DR was lower in polytraumatized patients than in others. This was because of the high complexity in these patients and their difficult management. On exposed evidence, we believe that CT with oral water-soluble contrast can be useful in patients in whom DR is highly suspected.

Surgical management is mandatory and requires the reduction of herniated content, repair of the defect, and occasionally, drainage of the pleura. This surgical management can be achieved by thoracic or abdominal approach. ${ }^{[2]}$ Our most common surgical approach was laparotomy (four median and six subcostal) because of the type of trauma and hemodynamic instability of the patients. Surgical procedure included thoracotomy only in four patients and laparotomy was added for one patient to reduce herniated contents. Thoracotomy was the preferred approach described by Schummer ${ }^{[25]}$ and Kotoulas. ${ }^{[26]}$ Igai ${ }^{[27]}$ chose posterolateral thoracotomy plus right subcostal laparotomy.

Thoracoscopy, laparoscopy, or both approaches combined have been described in the literature as useful methods to diagnose and treat DR, even in acute trauma. ${ }^{[28,29]}$ Some authors have reported that endoscopic freeing is often difficult in chronic $\mathrm{DH}(\mathrm{CDH})$ because of the strong adhesions between the herniated viscera and pleura. ${ }^{[30]}$ However, several authors have reported good results of the laparoscopic repair of $\mathrm{CDH} .{ }^{[8,31-35]}$ Liao et al have reported rapid recovery and decreased postoperative hospital stay after applying the pledgeted suture method in $\mathrm{CDH}$ treatment that involves compressing and approximating the edges of the diaphragm together and releasing the shearing force when applying ties. ${ }^{[36]}$

In our opinion, considering the addition of a thoracotomy in an unmanageable patient, laparotomy represents the best choice of treatment in cases of complex thoracic and abdominal acute trauma because it allows the widest abdominal view to search for any other injuries. In our case series, thoracotomy alone was performed in two patients with delayed DR and in one patient with acute DR. This last patient had exhibited hemodynamic stability at arrival and the presence of a negative abdominal CT scan.

Primary repair is the gold standard for small- or moderate- 
size diaphragmatic defects, whereas large defects (larger than $10 \mathrm{~cm}$ ) may require patch closure with a mesh. In emergency surgery, patch closure is not usually recommended. Polytetrafluoroethylene, polyethylene terephthalate, and polypropylene are the most common materials used in prosthetic patches to repair DR; some cases with patch infection followed by hernia recurrence have been reported in the literature. ${ }^{[37]}$ We believe that primary repair with non-absorbable sutures is the best technique for diaphragm repair and that prosthetic mesh should be placed when a lack of substance is detected, as usually occurs in delayed presentation of DR.

Pulmonary complications are reported to be the most common postoperative occurrence. ${ }^{[38]}$ Our experience supports this evidence. Associated organ injuries, hemorrhagic shock, missing or delayed diagnosis, rather than the DR itself, result in increased morbidity and mortality. ${ }^{\left[{ }^{3,39]}\right.}$ Other authors have reported no worsening of prognosis with delayed diagnosis followed by surgical repair. ${ }^{[19]}$ In the literature, mortality rates in patients with acute diaphragm injury differ from those in patients with delayed $\mathrm{DH}^{\left[{ }^{[3,5,38]}\right.}$ In our case series, delayed diagnosis and age were not factors affecting patient outcomes. Furthermore, the low mortality rate recorded (one patient) did not reveal a significant association between reported associated injuries and outcomes.

In conclusion, we can affirm that DR remains a diagnostic challenge because of nonspecific symptoms and signs and low sensitivity of imaging methods. DR repair is mandatory, and prosthetic mesh should be placed when a large DR is detected. It is not possible to define the best management considering the low incidence of DR, the acute setting, and variety of presentation, and diagnostic and treatment options. It is fundamental to maintain high clinical suspicion index in highrisk and compromised trauma patients.

\section{Conflict of interest: None declared.}

\section{REFERENCES}

1. Rajesh S, Sabaratnam S, Alan JM, Amit KC. Traumatic rupture of diaphragm. Ann Thorac Surg 1995;60:1444-9. [CrossRef]

2. Sandstrom CK, Stern EJ. Diaphramatic hernias: a spectrum of radiographic appearances. Curr Probl Diagn Radiol 2011;40:95-115.

3. Kaw LL Jr, Potenza BM, Coimbra R, Hoyt DB. Traumatic diaphragmatic hernia. J Am Coll Surg 2004;198:668-9. [CrossRef]

4. Shanmuganathan K, Killeen K, Mirvis SE, White CS. Imaging of diaphragmatic injuries. J Thorac Imaging 2000;15:104-11. [CrossRef]

5. Matsevych OY. Blunt diaphragmatic rupture: four year's experience. Hernia 2008;12:73-8. [CrossRef]

6. Grimes OF. Traumatic injuries of the diaphragm: diaphragmatic hernia. Am J Surg 1974;128:175-81. [CrossRef]

7. Goh BK, Wong AS, Tay KH, Hoe MN. Delayed presentation of a patient with a ruptured diaphragm complicated by gastric incarceration and perforation after apparently minor blunt trauma. CJEM 2004;6:277-80.

8. Rashid F, Chakrabarty MM, Singh R, Iftikhar SY. A review on delayed presentation of diaphragmatic rupture. World J Emerg Surg 2009;4:32.

9. Lee HY, Yoo SM, Song IS, Yu H, Kim YS, Lee JB, Shon DS. Spontane- ous diaphragmatic rupture after vomiting: rapid diagnosis on multiplanar reformatted multidetector CT.J Thorac Imaging 2006;21:54-6.

10. Guth AA, Pachter HL, Kim U. Pitfalls in the diagnosis of blunt diaphragmatic injury. Am J Surg 1995;170:5-9. [CrossRef]

11. Killeen KL, Mirvis SE, Shanmuganathan K. Helical CT of diaphragmatic rupture caused by blunt trauma. AJR 1999;173:1611-6.

12. Reber PU, Schmied B, Seiler CA, Baer HU, Patel AG, Buchler MW. Missed diaphragmatic injuries and their long-term sequel. J Trauma 1998;44:183-8. [CrossRef]

13. Yilmaz M, Isik B, Ara C, Yilmaz S, Kutlu R, Kocak O, et al. Gastric perforation during chest tube placement for acute diaphragmatic rupture and review of the literature. Injury Extra 2006;37:71-5. [CrossRef]

14. Simpson J, Lobo DN, Shah AB, Rowlands BJ. Traumatic diaphragmatic rupture: associated injuries and outcome. Ann R Coll Surg Engl 2000;82:97-100.

15. Murray JG, Caoili E, Gruden JF, Evans SJJ, Halvorsen RA Jr, Mackersie RC. Acute rupture of the diaphragm due to blunt trauma: diagnostic sensitivity and specificity of CT. AJR 1996;66:1035-9. [CrossRef]

16. Popovic T, Nikolic S, Radovanovic B, Jovanovic T. Missed Diaphragmatic Rupture and Progressive Hepatothorax, 26 Years after Blunt Injury. European Journal of Trauma 2004;30:43-6. [CrossRef]

17. Zedan M, El-Ghazaly M, Fouda A, El-Bayoumi M. Tension gastrothorax: a case report and review of literature. J Pediatr Surg 2008;43:740-3.

18. Matsumoto N, Oki E, Morita M, Kakeji Y, Egashira A, Sadanaga N, et al. Successful treatment of acute esophageal necrosis caused by intrathoracic gastric volvulus: report of a case. Surg Today 2009;39:1068-72.

19. Arak T, Solheim K, Pillgram-Larsen J. Diaphragmatic injuries. Injury 1997;28:113-7. [CrossRef]

20. Alimoglu O, Eryilmaz R, Sahin M, Ozsoy MS. Delayed traumatic diaphragmatic hernias presenting with strangulation. Hernia 2004;8:393-6.

21. Hwang S, Kim H, Byun JH. Management of patients with traumatic rupture of the diaphragm. Korean J Thorac Cardiovasc Surg 2011;44:34854. [CrossRef]

22. Gelman R, Mirvis SE, Gens D. Diaphragmatic rupture due to blunt trauma: sensitivity of plain chest radiographs. AJR Am J Roentgenol 1991;156:51-7. [CrossRef]

23. Iochum S, Ludig T, Walter, Sebbag H, Grosdidier G, Blum AG. Imaging of diaphragmatic injury: a diagnostic challenge? Radiographics 2002;22:103-16. [CrossRef]

24. Walchalk LR, Stanfield SC. Delayed presentation of traumatic diaphragmatic rupture. J Emerg Med 2010;39:21-4. [CrossRef]

25. Schummer W, Schummer C, Gottschall, Schumann M. Delayed diagnosis of right-sided diaphragmatic rupture. Accid Emerg Nurs 2003;11:24. [CrossRef]

26. Kotoulas C, Chouliaras E, Siarapis P, Nisotakis K. Right diaphragmatic rupture and hepatic hernia: a rare late sequela of thoracic trauma. Eur J Cardiothorac Surg 2004;25:1121. [CrossRef]

27. Igai H, Yokomise H, Kumagai K, Yamashita S, Kawakita K, Kuroda Y. Delayed hepatothorax due to right-sided traumatic diaphragmatic rupture. Gen Thorac Cardiovasc Surg 2007;55:434-436. [CrossRef]

28. Friese RS, Coln CE, Gentilello LM. Laparoscopy is sufficient to exclude occult diaphragm injury after penetrating abdominal trauma. J Trauma 2005;58:789-92. [CrossRef]

29. Singal R, Gupta R, Mittal A, Gupta A, Singal RP, Singh B, et al. Delayed presentation of the traumatic abdominal wall hernia; dilemma in management - review of literature. Indian J Surg 2012;74:149-56. [CrossRef]

30. Mitchell IC, Garcia NM, Barber R, Ahmad N, Hicks BA, Fisher AC. Permacol: a potential biologic patch alternative in congenital diaphragmatic hernia repair. J Pediatr Surg 2008;43:2161-64. [CrossRef]

31. Torresini G, Sozio L, Crisci R, Amicucci G. Laparoscopic repair of diaphragmatic iatrogenic hernia. Endoscopy 2002;32:2.

32. Matthews BD, Bui H, Harold KL, Kercher KW, Adrales G, Park A, et al. Laparoscopic repair of traumatic diaphragmatic injuries. Surg Endosc 
2003;17:254-8.

33. Schneider C, Tamme C, Scheidbach H, Delker-Wegener S, Köckerling F. Laparoscopic management of traumatic ruptures of the diaphragm. Langenbecks Arch Surg 2000;385:118-23. [CrossRef]

34. Fiscon V, Portale G, Migliorini G, Frigo F. Laparoscopic repair of intrathoracic liver herniation after traumatic rupture of the diaphragm. Surg Endosc 2011;25:3423-5. [CrossRef]

35. Baldwin M, Dagens A, Sgromo B. Laparoscopic management of a delayed traumatic diaphragmatic rupture complicated by bowel strangulation. J Surg Case Rep 2014;7. [CrossRef]

36. Liao CH, Chu CH, Wu YT, Fu CY, Hsieh FJ, Wang SY, et al. The feasi- bility and efficacy of laparoscopic repair for chronic traumatic diaphragmatic herniation: introduction of a novel technique with literature review. Hernia 2016;20:303-9. [CrossRef]

37. Güner A, Özkan ÖF, Bekar Y, Keçe C, Kaya Ü, Reis E. Management of delayed presentation of a right-side traumatic diaphragmatic rupture. World J Surg 2012;36:260-5. [CrossRef]

38. Sözüer EM, Ok E, Avşaroğullari L, Küçük C, Kerek M. Traumatic diaphragmatic ruptures. Ulus Travma Derg 2001;7:176-80.

39. Hanna WC, Ferri LE, Fata P, Razek T, Mulder DS. The current status of traumatic diaphragmatic injury: lessons learned from 105 patients over 13 years. Ann Thorac Surg 2008;85:1044-8. [CrossRef]

\section{OLGU SERİII - ÖZET}

\section{Diyafragma rüptürü: Tek bir kurum deneyimi ve literatürün gözden geçirilmesi \\ Dr. Carlo Corbellini, Dr. Stefano Costa, Dr. Tiberio Canini, Dr. Roberta Villa, Dr. Ettore Contessini Avesani}

IRCCS Cà Granda Vakfı, Maggiore Hastanesi Polikliniği, Genel Cerrahi ve Acil Cerrahi Kliniği, Milan-ittalya

AMAÇ: Diyafragma rüptürü (DR) seyrek görülen, travma sonucu veya kendiliğinden oluşan yaşamı tehdit edici potansiyeli olan bir olaydır. Bazen DR yaralanmadan birkaç ay sonra oluşur. Göğüs filmi ve bilgisayarlı tomografi en etkili tanısal yöntemlerdir. Sıklıkla DR tanısı gecikir. Bu çalışmanın amacı DR etiyoloji, klinik tablosu ve tedavisini incelemek ve daha iyi anlamaktır.

GEREÇ VE YÖNTEM: Bu çalışma İtalya, Milano I.R.R.C.S. Vakfı Cà Granda Hastanesi Acil ve Genel Cerrahi Bölümü Polikliniği’nde [Emergency and General Surgery Department of Fondazione I.R.R.C.S. Cà Granda, Ospedale Policlinico in Milan (Italy)] gerçekleştirildi. 200I ila 20 I I yılları arasında DR tanısı konup ameliyat geçirmiş hastalar çalışmaya dahil edilip geriye dönük olarak hastaların verileri toplandı.

BULGULAR: Çoğu sağ tarafta DR olan 14 hastaya tanı konmuştur. Başlıca neden trafik kazalarıydı (\%86). Sekiz hastada (\%57) ameliyat öncesi DR tanısı konmuştu. Göğüs filmi hastaların \%50'sine tanı koydurmuş, üç olguda (\%60) bilgisayarlı tomografi yararlı olmuştur. On iki hastada diyafragma hernisi mevcuttu. İki olguda DR meş ile onarılmıştır. Ortalama hastanede kalış süresi 16.6 gün idi.

TARTIŞMA: Nonspesifik kliniği nedeniyle erken tanı koymada zorluk yaşanmaktadır. Çok kuşkucu olmak gerekir, tedavisi cerrahidir. İç organlar içeri itilir ve diyafragma defekti onarılır.

Anahtar sözcükler: Diyafragma hernisi; diyafragma rüptürü; spontan diyafragma rüptürü; travmatik diyafragma rüptürü.

Ulus Travma Acil Cerrahi Derg 2017;22(5):42I-426 doi: 10.5505/tjtes.2017.78027 